\title{
RELAÇÕES ENTRE O MERCADO, A CIDADE E A BORDA DÁGUA EM ESPAÇOS CENTRAIS DE CIDADES LITORÂNEAS Estudo de Caso de Laguna, Florianópolis e São Francisco do Sul.
}

\author{
Tueilon de Oliveira \\ PósArq - Programa de Pós-Graduação em Arquitetura e Urbanismo \\ Universidade Federal de Santa Catarina. \\ Orientador: Dr. Juan Antonio Zapatel \\ tueilon@hotmail.com
}

\section{RESUMO}

Este trabalho apresenta um estudo sobre urbanidade em centros históricos de cidades litorâneas. Como objeto de pesquisa foram selecionadas as cidades de Laguna, Florianópolis e São Francisco do Sul, no litoral do estado de Santa Catarina, Brasil. A metodologia utilizada tem abordagem qualitativa e exploratória, que pretende conciliar o olhar axial e panorâmico do planejamento com o olhar intimista e humanista do indivíduo, buscando com isso compreender aspectos de urbanidade. O método envolve pesquisa iconográfica em arquivos municipais e estaduais, levantamento das áreas de estudo no registro de informações urbano-arquitetônica e utiliza os cortes urbanos como instrumento de leitura em paralelo com o método etnográfico do diário de campo. Os resultados introduzem formas de apropriação em centros históricos costeiros de cidades luso-brasileiras e a interação entre o mercado público, a orla aquática e os aspectos de urbanidade que se apresentam nestes espaços.

Palavras-chave: Urbanidades; Mercados públicos; Orlas marítimas; Vivências urbanas;

\begin{abstract}
This paper presents a study about historical centers on coastal cities. As object of study were selected the cities of Laguna, Florianopolis and Sao Francisco do Sul, on the coast of the State of Santa Catarina, Brasil. The methodology applied has qualitative and exploratory approach, which pretends to conciliate the axialpanoramic planning view, alongside the intimate and humanistic individual look seeking understand faces of urbanity. The method involves iconographic research on state and municipal historical files, analysis of the study areas at the record of urban-architectural information and uses the urban section as reading instrument alongside the ethnographic method of field diary. The results introduce appropriation on historic centers of Portuguese-Brazilian cities and the interaction between the public market, the seashore and the urbanities outlook presented on these spaces.
\end{abstract}

Keywords: Urbanities; Public markets; Seafront; Urban living; 


\section{INTRODUÇÃO}

O início da constituição de uma cidade remete aos espaços de convívio das pessoas em paralelo com atividades de cunho comercial, escambo e troca de bens e mercadorias. Seja um posto comercial, um entreposto, um porto ou um ponto de parada, as cidades surgiram perante a necessidade de um espaço de ir e vir, um espaço de encontro onde indivíduos passariam a comprar, vender e trocar bens de acordo com seus interesses mútuos.

Esse contexto é materializado no núcleo original dos assentamentos: a praça, a rua do comércio, a igreja, o mercado público e seu entorno imediato com as primeiras edificações, sendo que, nas cidades litorâneas é evidente como a morfologia destes espaços se relaciona diretamente com a borda d'agua. Considerando a urbe como resultado da ação antrópica sobre (e a partir) do meio ambiente (PESAVENTO, 2008), os espaços de ocupação inicial em cidades litorâneas foram concebidos sobre a necessidade de uso da água como ponto principal de abastecimento e transporte, definindo funções essenciais para a manutenção da vida urbana.

Este estudo busca compreender as diferentes interações que existem entre a cidade litorânea, os edifícios, as pessoas e a água, abordando os espaços centrais com foco na sua interação com o mercado público.

\section{PRESSUPOSTOS TEÓRICO-METODOLÓGICOS}

Esta seção apresenta a base teórica que precede e suporta esta pesquisa. Foram explorados estudos acerca da imagem e da paisagem urbana, memória e apropriação do espaço, espacialidades e urbanidades.

\subsection{AS CIDADES E AS ÁGUAS}

A presença da água poetiza a arquitetura. (PALLASMAA, 2013, p. 50)

Cursos d'agua, de maneia geral, tiveram papel de destaque na história das civilizações. Constituíam marcos territoriais e paisagísticos, contribuíam para a produção de alimentos, delimitavam território e serviam como corredores de transporte de cargas e pessoas. Eram espaços públicos livres e geradores de energia, dentre outras funções. O próprio mercado público pode ser tomado como exemplo de equipamento urbano que tem sua implantação de acordo com a orla. (MELLO, 2008; GORSKI, 2010)

O historiador Alain Corbin (1989) faz uma incursão sobre as mudanças nos olhares lançados sobre o mar e as praias no imaginário ocidental e sobre como o conceito de utilização do litoral evoluiu com o passar do tempo. Corbin (1989, p. 7) afirma que "Não há outros meios de conhecer os homens do passado a não ser tomando emprestado seus olhares, vivendo suas emoções;", excerto que pode ser tomado como premissa para compreender como a percepção do mar contribuiu para com a constituição e definição morfológica das cidades litorâneas luso-brasileiras. O pensamento religioso que outrora determinava um modo de viver das pessoas incidiu diretamente sobre a cultura ocidental e logo, no modo de construção das cidades. (CORBIN, 1989). O mar, a forma irregular da costa e o próprio cheiro das praias condensam um sentimento de medo e repulsa.

As praias e as dunas não são vistas como resultado da erosão, mas como elementos de uma arquitetura, edificada após o dilúvio. O desenho dos golfos e das baías atende ao projeto divino; tem por finalidade fornecer um abrigo aos navios e possibilitar o transporte das mercadorias para o interior dos continentes. (CORBIN, 1989, p. 39)

Os oceanos assinalavam o limite do desconhecido, permeado pela sombra de criaturas marinhas e pela maior variedade de monstros. Nesse período os mares podem ser tomados como vítima da ignorância humana, exímia em temer e evitar o desconhecido para, a partir disso, condená-lo (CORBIN, 1989). O mar simbolizava então o medo, o desconhecido, a ameaça e a loucura. As praias formavam um limite entre 0 mundo são, íntimo e ordenado, e a confusão e desordem do mar.

Como em outras áreas e grupos de conhecimento, gradativamente se instala uma mudança nos olhares e pensamentos sobre o domínio marítimo. A partir do século XVII "os mistérios do oceano dissipam-se graças aos progressos realizados, na Inglaterra, pela oceanografia." (CORBIN, 1989, p. 28) Concomitantemente, o 
mar se torna objeto da poesia francesa, que descreve o prazer e a alegria despertados no cenário litorâneo, ao passo que as praias são objetificadas por uma elite que busca na vilegiatura marítima um retorno à natureza.

Esse temor do mar e do desconhecido torna-se determinante nos padrões de morfologia urbana portugueses, à exemplo, a implantação da igreja: situava-se majoritariamente em local de topografia elevada e dominante na paisagem, com o intuito de proteger a urbe dos perigos que podem se aproximar pela água.

\subsection{A CIDADE PORTUGUESA}

O modelo da cidade portuguesa foi fortemente replicado e implantado além dos limites da península ibérica com a expansão ultramarina do século XV. Os padrões morfológicos das cidades portuguesas foram então aplicados e adaptados às realidades dos novos sítios, de acordo com as novas tipologias de materiais, mão de obra, assim como das condições ambientais e topográficas do sítio. ${ }^{1}$ (MARX, 1980; TEIXEIRA, 2011) A morfologia urbana da cidade portuguesa apresenta características bastante particulares e que, portanto, a diferenciam de outras culturas. Teixeira (2011, p. 151) afirma que:

Dentre os fatores determinantes para a estruturação das cidades portuguesas, ocupam papel fundamental a geografia e a topografia do terreno, o clima, a natureza do solo e os materiais disponíveis para a construção. Fatores de ordem cultural, em que se incluem os valores sociais, políticos, morais e religiosos que estruturam uma sociedade, vêm articularse com aqueles fatores físicos, expressando-se também nas formas de organização urbana.

São as relações entre estes componentes (físicos e culturais) que definem a estrutura organizacional da cidade luso-brasileira. $O$ primeiro grupo de fatores pode ser notado na locação da malha urbana que mantém uma integração forte com o sítio. $O$ traçado português é flexível e se adapta à condições topográficas, mostrando-se inteligente nessa flexibilidade e na sua "preocupação de adaptar o plano, e a sua geometria às preexistências, fossem elas naturais ou construídas pelo homem". (TEIXEIRA, 2011, p. 153), sendo sua característica principal essa "síntese de um plano racionalmente estruturado com uma cuidadosa adaptação ao sítio." (TEIXEIRA, 2011, p. 160)
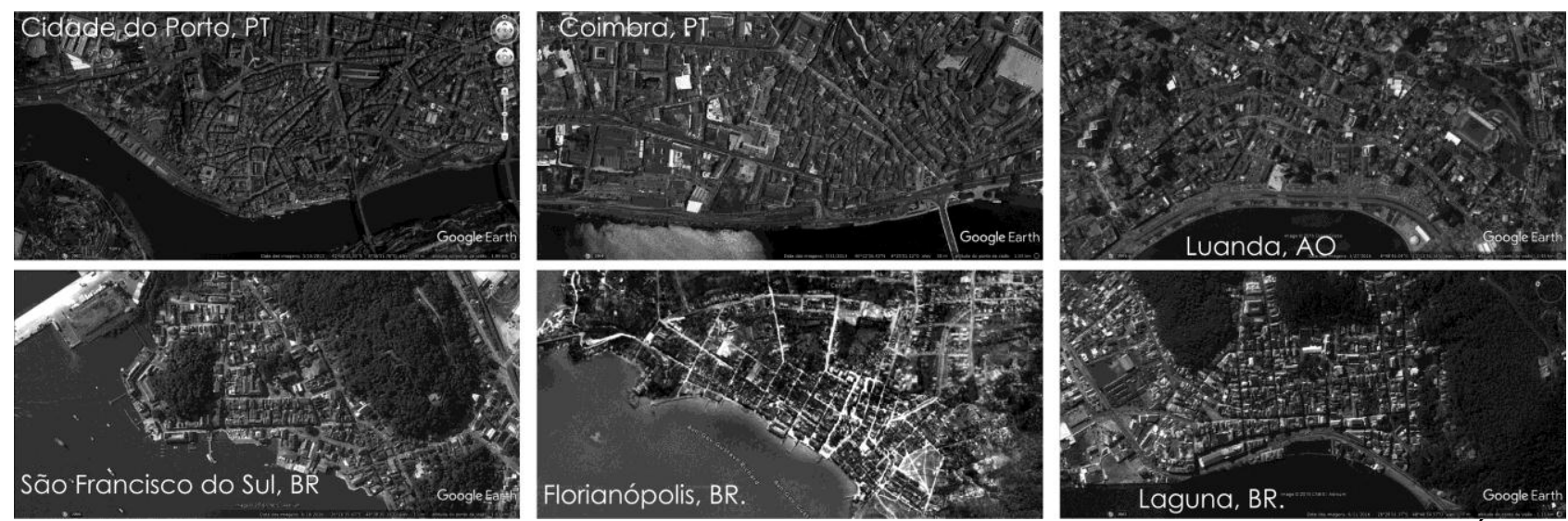

Figura 1 Imagens de Satélite mostram as semelhanças entre cidades de origem portuguesa espalhada entre Europa, Africa e América.

Fonte: adaptado de maps.gogle.com

As cidades portuguesas mantinham um padrão ainda medieval de ocupação no território com base em estratégias militares. "Se os portos bons atraíam os portugueses, eram atraentes também para os seus rivais. Por isso, além do remanso importava igualmente a defesa." (MARX, 1980, p. 20). Não obstante, os padrões de ocupação das cidades portuguesas podem ser notados não somente por fatores morfológicos: 0 próprio sítio de implantação dos assentamentos e seu posicionamento em relação à água era determinado com base nos padrões imperiais. (figura 1)

\footnotetext{
${ }^{1}$ É interessante observar a reciprocidade com que esse processo ocorre. Após um período de tempo, as novas morfologias urbanas desenvolvidas nas colônias - Brasil, Madeira e Açores - acabam sendo também aplicadas em Portugal. (TEIXEIRA, 2011)
} 


\section{3}

\section{O LUGAR DO MERCADO}

É importante aludir o destaque e o papel do mercado público dentro da estrutura da cidade luso-brasileira. Como mencionado, espaços de troca marcam a centralização e constituição das cidades. O mercado público é, em um primeiro momento, a porta de entrada da cidade, tanto para pessoas quanto para mercadorias.

Os mercados municipais merecem destaque pelo seu importante papel econômico e social, a partir do século passado, e pelo novo elemento característico que introduziram na nossa paisagem urbana. Geralmente de banda e na borda da cidade, vieram os mercados enriquecer o cenário existente com prédios singelos de madeira ou de alvenaria, com simples coberturas ou pátios fechados, com construções mais audaciosas a introduzir entre os materiais empregados o ferro e o vidro. São todos símbolo da ação reguladora do Estado e da sua responsabilidade para com o abastecimento de uma gente citadina, que não planta o que come. (MARX, 1980, p.82)

Considerando a arquitetura como representativa de momentos do homem e dotada de significados, pode-se traçar uma linha de interpretação que busca conhecer um edifício em aspectos que transcendem a sua forma e função e tocam questões subjetivas no inconsciente coletivo: a destruição da Bastilha, pelos franceses, simboliza a supressão de séculos de dor e abuso materializados na forma arquitetônica do edifício. A criação de Brasília, proposta por Juscelino Kubitschek, transcendia a materialidade da construção urbana e tocava os ideais de renovação da pátria e de progresso. Por outro lado, os hospitais imprimem nas pessoas sentimentos de vazio, dor, perda, fraqueza enquanto a arquitetura religiosa transmite transcendência, exultação.

E que sentimentos e sensações estão impressos na arquitetura do mercado? Além do uso comercial propriamente dito, o mercado passa a ser um símbolo citadino, sinônimo da prosperidade,, palco de eventos, manifestações culturais e cívicas e polo de atração turística. (TEIXEIRA, 2002; YAMAMOTO, 2008) principalmente ao considerar a ausência de edifícios de caráter público e governamental na cidade lusobrasileira.

\section{$2.4 \quad$ URBANIDADES}

[...] a urbanidade pode se dar em qualquer lugar onde convirjam pessoas e edifícios. (IBELINGS, Hans. Urbanidad, In SOLÁ-MORALES, Manuel, De Cosas Urbanas, 2008, p. 13 tradução nossa) $)^{2}$

O meio urbano pode ser visto como um canal mediador dos nossos atos, e sob essa ótica, a morfologia urbana é determinante em nosso modo de experimentação do mundo (figura 2), logo, diferentes urbanidades geram diferentes experiências de vida. As cidades, em sua maioria, com exceção àquelas planejadas inteiramente, são formadas por um processo gradual e contínuo de crescimento e reformulação. Esse processo de criação do espaço garante em si certa legibilidade, que pode ser desconstruída através da implantação de um elemento de grande porte, com peso suficiente para desequilibrar este cenário urbano. $^{3}$ (LYNCH, 1997)

\footnotetext{
2 “[...] la urbanidade pode darse em cualquier lugar en el que converjan personas y edifícios" (IBELINGS, Hans. Urbanidad, In SOLÁMORALES, Manuel, De Cosas Urbanas, 2008, p. 13 texto original)

${ }^{3}$ Para este estudo, a implantação do aterro Baía Sul, em Florianópolis, possui essa propriedade para desequilibrar o meio urbano.
} 

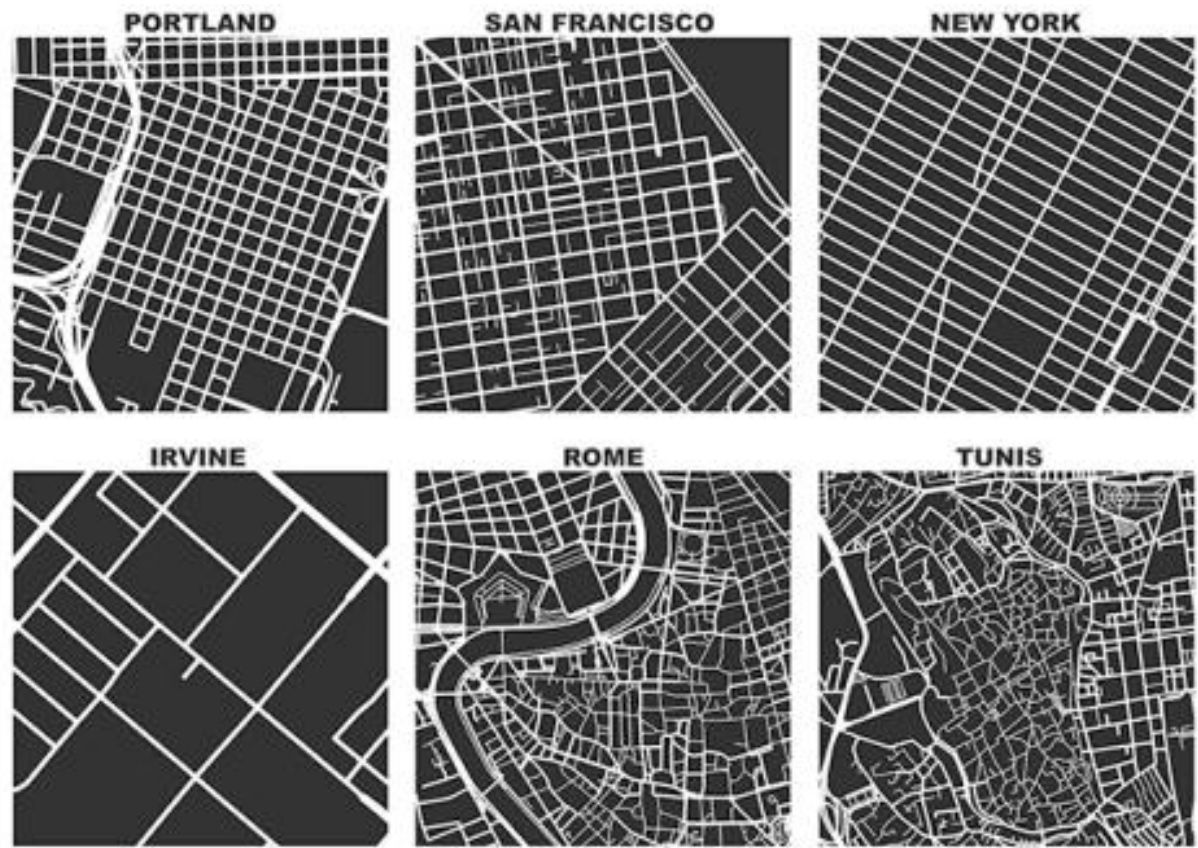

Figura 2 Diferentes malhas urbanas geram diferentes experiências e urbanidades.

http://mentalfloss.com/article/92200/what-square-mile-citys-grid-looks-around-world

É importante considerar que o conceito de urbanidade não é fácil de ser compreendido. Muitos autores têm explorado a urbanidade como objeto de pesquisa, e como resultado não é revelada uma urbanidade completa, sólida, palpável; outrossim, são apresentados nuances de uma urbanidade complexa e de difícil compreensão.

Netto (2013) não aborda a urbanidade como uma definição, mas sim como conceitos a serem explorados e a partir dos quais são delineados traços da urbanidade; (1) a urbanidade vista como forma de experimentação e diferenciação das experiências urbanas; (2) a urbanidade como experiência de reconhecimento da diferenciação de meios sociais; (3) a urbanidade como uma "experiência de transcendência das diferenças sociais" (NETTO, 2013, p. 118); e (4) urbanidade como sobreposição das diferenças sociais e propulsora do encontro.

Krafta (2012), assim como Netto (2012-13) relaciona urbanidades aos efeitos da relação entre espacialidades e os tempos urbanos. A cidade, ou a grande maioria delas, seria um resultado da composição de objetos 'produzidos em diferentes tempos por diferentes indivíduos', ou seja, novos objetos ou componentes urbanos sendo constantemente inseridos em meio a pré-existências. Segundo Krafta (2012), essa sobreposição pode ocorrer de três maneiras distintas: [a] inserção de objetos visando a homogeneidade da forma; [b] a inserção de objetos formando uma 'diversidade de domínios locais homogêneos; [c] uma inserção constante de objetos que modifica a concepção do conjunto pré-existente, apresentando um novo aglomerado com um significado diferente.

Aguiar (2012) trata a urbanidade como característica física, ligada a propriedades dos elementos que compõem o meio urbano e que afeta diretamente o comportamento das pessoas e a forma de apropriação do espaço público. De forma semelhante, o arquiteto catalão Solà-Morales (2008) apresenta uma "urbanidade material", que surge na cidade e a partir dela. Como o autor menciona: "Me interessa a urbanidade do material, a urbanidade de tato e visão, de sensações e propostas." (SOLÀ-MORALES, 2008, p. 23 tradução nossa) ${ }^{4}$

Para Solà-Morales (2008), a arquitetura e o urbanismo devem ser vistos como extensões de si mesmos, e não como disciplinas independentes. Essa relação entre arquitetura e urbanismo converge na 'piel de la ciudad' (a pele da cidade) que vem a se tornar seu objeto de estudo, tratada como plano de trabalho para se encontrar a urbanidade material. Essa visão explora a epiderme como variante ativa nas dinâmicas

\footnotetext{
4 "Me interesa la urbanidad de lo material, la urbanidad de tacto y de visión, de sensaciones y de sugerencias." (SOLÀ-MORALES, 2008 , p. 23 texto original)
} 
urbanas e desse modo sua compreensão se torna essencial para o entendimento da urbanidade e também para a concepção de projetos urbanos.

\subsection{ESPACIALIDADE URBANA}

Seguindo o conceito de urbanidades, apresentado na seção anterior, a arquitetura - presente no objeto arquitetônico assim como no contexto urbano - possui um potencial para moldar nosso modo de viver e experimentar o mundo. É interessante considerar, não obstante, que o homem, quando habita um espaço arquitetônico não habita o objeto em si, mas apropria-se do vazio espacial que ele o objeto (ou conjunto) arquitetônico conforma. A arquitetura configura a espacialidade "a partir da constatação de que o limite de cada objeto seria, de modo estrito, também o limite do corpo de ar que o cerca." (AGUIAR, 2010, p. 22) Logo, a urbanidade pode ser definida por essas relações entre a edificação e o vazio, este que se torna objeto de estudo da teoria espacial.

Aguiar (2010) trata da condição espacial estruturada a partir do corpo em movimento no espaço. Com base nessa premissa, no sentido oposto aos estudos sobre a matéria arquitetônica, "a pesquisa da espacialidade ocupa-se das características e propriedades do vazio, o espaço deixado livre entre objetos, a forma desse vazio, seu arranjo tanto na escala do interior dos edifícios quanto na escala dos interiores urbanos." (AGUIAR, 2010, p. 18).

Sobre essa perspectiva, é de extrema relevância o papel do indivíduo, numa visão antropocêntrica, como observador ativo dessa experimentação espacial. O homem constrói o meio com base na sua experiência, comportamentos e necessidades previamente conhecidos; o espaço criado, por sua vez, torna a definir novas formas de utilização e apropriação e novos padrões comportamentais.

\subsection{EXPERIMENTAÇÃO E VIVÊNCIAS URBANAS}

A arquitetura é definida pela antropometria, tendo o homem como medida para todas as coisas. Desse modo, é possível afirmar que a organização espacial se fundamenta na estrutura e postura do corpo humano e na sua forma de interação com o meio: os sentidos. O arquiteto finlandês Juhani Pallasma (201113) faz uma análise sobre o que seria uma "arquitetura corporificada", enfatizando o espaço arquitetônico que permite ao observador uma experiência multissensorial. Conforme Pallasmaa (2011, p. 42), "Uma obra de arquitetura não é experimentada como uma coletânea de imagens visuais isoladas, e sim em sua presença material e espiritual totalmente corporificada. Uma obra de arquitetura incorpora e infunde estruturas tanto físicas quanto mentais." Seguindo a mesma corrente de pensamento, Tuan (1983, p. 14) assume que:

O paladar, o olfato, a sensibilidade da pele e a audição não podem individualmente (nem sequer talvez juntos) nos tornar cientes de um mundo exterior habitado por objetos. No entanto, em combinação com as faculdades 'espacializantes' da visão e do tato, estes sentidos essencialmente não distanciadores enriquecem muito nossa apreensão do caráter espacial e geométrico do mundo.

Essa polifonia dos sentidos pode ser facilmente identificada em ambientes naturais: uma floresta agrada a visão tanto quanto o olfato, o tato e a audição, e por conta disso torna-se uma experiência tão imersiva. A arquitetura vista como uma extensão da natureza na esfera antrópica deve então, de modo semelhante, se mostrar multissensorial para gerar uma experiência completa e enriquecedora para as pessoas. Seguindo essa premissa, cada rua ou segmento de rua de uma cidade pode ser caracterizado por alguma característica singular, seja um som característico ou cheiro próprio de algum estabelecimento comercial (padaria ou perfumaria). No caso das cidades litorâneas, espera-se avaliar (com a aplicação método do diário de campo) de que forma a borda d'água e a região no entorno do mercado público pode possuir características multissensoriais geradoras de identidade e reconhecimento para as pessoas.

\section{METODOLOGIA}

Esta pesquisa contempla um estudo com abordagem qualitativa e exploratória, sendo organizado em três etapas distintas: levantamento teórico, estudo comparativo e por fim a discussão dos resultados e conclusão. 
O levantamento teórico, apresentado na seção anterior, tem objetivo de contextualizar e embasar a pesquisa apresentando ideais que se relacionam com o tema e permitam uma compreensão aprofundada sobre os casos analisados.

O estudo de caso comparativo foi realizado na área central das cidades de Laguna, Florianópolis e São Francisco do Sul (SC). Envolve pesquisa iconográfica em arquivos municipais e estaduais, e o levantamento das áreas de estudo no registro de informações urbano-arquitetônicas que configuram os espaços à beira-mar e sua realidade atual. $\mathrm{O}$ método de análise do estudo comparativo será estruturado pelos seguintes instrumentos metodológicos:

a) Análises in loco, visando catalogar aspectos físicos, morfológicos, geográficos e demográficos da orla e do mercado público;

b) Análises sobre fluxos, limites, barreiras e rupturas: Etapa do diagnóstico da área que busca compreender os níveis de acessibilidade da área aos seus usuários, identificar os elementos que condicionam o espaço urbano e os possíveis níveis de interação correspondentes;

c) Elaboração dos cortes urbanos, de acordo com o método elaborado por Solá-Morales (2008) como ferramenta de pesquisa apta a sintetizar as relações entre a cidade e a água, entre a edificação e a rua, e também captar aspectos de urbanidade material ${ }^{5}$.

d) Elaboração e registro do Diário de Campo como instrumento de pesquisa qualitativa que permite um olhar "de perto e de dentro" (MAGNANI, 2002), como forma de complementar as análises anteriores e permitir um olhar intimista e humanizado sobre as áreas analisadas.

e) Estudo comparativo sobre os tempos urbanos das Cidades de Laguna, Florianópolis e São Francisco do Sul (SC) com intuito de abordar potencialidades e vulnerabilidades presentes na relação cidade $x$ mar sob a ótica do mercado público como 'fato urbano'6 mediador das dinâmicas locais.

\subsection{OS CORTES COMO LEITURA URBANA}

As cidades, de certa forma, são massas edificadas seccionadas por uma rede de espaços públicos, estes, distribuídos em ruas, avenidas, calçadões, praças e parques, etc. Desse modo, pode-se assumir que as pessoas vivenciam a cidade ao traçar cortes lineares durante seus percursos diários, seja para o trabalho, para a escola, para o teatro, em suma, qualquer deslocamento entre dois pontos distintos no tecido urbano. Solà-Morales (2008, p. 175) afirma que "Mover-se e caminhar continuamente, isso é pertencer à cidade. Sem nunca sair dela, porque não há fora."7

A partir dessa premissa, o autor utiliza a técnica do corte urbano como forma de explicar a anatomia das cidades e explorar a epiderme urbana de uma forma que se aproxime da visão cotidiana das pessoas.

A pele das cidades é feita de construções, texturas, contrastes; De ruas e espaços livres,
de jardins e muros, de perfis e vazios. [...] Também movimentos e encruzilhadas, veículos e
fachadas, porões e bueiros, tendas, escritórios, terrenos, apartamentos, museus, teatros e
todos os tipos de lugares vazios. Meios-fios e calçadas, lojas e armazéns, fábricas e
mercados, monumentos e ruínas, estações, estádios, estúdios, etc. (SOLÀ-MORALES,
2008 , p. 23 tradução nossa)

Os cortes ou seções urbanas exploram potencialmente estes elementos da superfície da urbe, mostrando as relações entre as edificações e a rua, entre o velho e o novo, entre espaço público e espaço privado, sem nunca deixar de apresentar a escala humana. Para Solá-Morales ." (2008, p. 179 tradução nossa), "A

\footnotetext{
${ }^{5} \mathrm{O}$ conceito de urbanidade material desenvolvido pelo arquiteto catalão Solà-Morales é apresentado na seção 2.6 deste trabalho.

${ }^{6} \mathrm{O}$ 'fato urbano' é apresentado como o conceito cunhado pelo arquiteto italiano Aldo Rossi, que os define como elementos formadores da cidade e parte integrante da sua história.

${ }^{7}$ Moverse y caminhar continuamente, esto es pertencer a la ciudad. Sin salir nunca de ella, porque no hay afuera" (SOLÀ-MORALES, 2008, p. 175)

8 "La piel de la ciudades está hecha de construcciones, texturas, contrastes. De calles y espacios libres, de jardins y muros, de perfiles y vacíos. [...] También movimentos y encrucijadas, vehiculos y fachadas, sótanos y conductos subterrâneos. Tiendas, oficinas, solares, apartamentos, museos, teatros y todo tipo de locales vacios. Bordillos y aceras, almanaces y depósitos, fábricas y mercados, monumentos y ruinas, estaciones, estádios, estúdios, etc." (SOLÀ-MORALES, 2008, p. 23 texto original)
} 
redução sequencial, o corte da forma urbana, é um mecanismo de descrição e uma estratégia de projeto ${ }^{9}$ É no corte urbano que pode ser notada a paisagem e a identidade urbana.

\subsection{ETNOGRAFIA URBANA}

O termo "etnografia" é bastante familiar para a sociologia, compreende um método de trabalho imerso no estudo das etnias e que, originalmente, tinha por objeto povos primitivos e excêntricos, comunidades vinculadas à caça e a pesca ou agricultura e de formas subsistência não vinculadas à urbanização; logo, externas ao pesquisador. Nesses casos, a distância entre o observador e o objeto era necessária - e até mesmo uma premissa - para possibilitar a aplicação do método.

Para a etnografia urbana, esse distanciamento entre pesquisador e objeto não é essencial; ao considerarmos que "a maneira de pensar quando o objeto é 'outro' e exige nossa própria transformação. "Assim, também viramos etnólogos de nossa própria sociedade, se tomarmos distância em relação a ela" (MERLEAU-PONTY apud MAGNANI, 2002, p. 16)

A etnografia urbana é uma variação (mais recente) do método etnográfico, dedicada aos estudos sobre padrões de comportamento no contexto citadino e que tem como objetivo reduzir a dicotomia entre as técnicas de: (i) análise do meio urbano através de planificações e mapas, que abrange uma grande área da cidade, em contraste com (ii); a relevância e o papel da pessoa, do indivíduo no emaranhado e na complexidade da metrópole.

É neste plano que entra a perspectiva de perto e de dentro, capaz de apreender os padrões de comportamento, não de indivíduos atomizados, mas dos múltiplos, variados e heterogêneos conjuntos de atores sociais cuja vida cotidiana transcorre na paisagem da cidade e depende de seus equipamentos (MAGNANI, 2002, p. 18).

O que se propõe neste estudo é então classificado como etnografia de passagem, descriminado por (i) a definição do pedaço ou recorte onde será aplicado o método do diário de campo. (ii) criação de um percurso espontâneo, de acordo com o que o pesquisador determinar como relevante e (iii) observação do comportamento das pessoas e sua relação com os demais, em paralelo com a dimensão cenestésica e sensitiva do espaço. (PALLASMAA, 2011, 2013; TUAN, 1983 AGUIAR; 2010).

A partir disso, foram determinados dois períodos de observação distintos, cada um com duração média de três horas, em dias úteis assim como em finais de semana, em cada cidade analisada. O recorte onde foi aplicado o diário de campo é definido por um raio de $350 \mathrm{~m}$, cujo epicentro é formado pelo mercado público, e os percursos foram balizados através dos equipamentos de maior porte e relevância para a área, a saber: o mercado público, a orla, a praça e a igreja. Sob a forma de anotações, e com o auxílio de fotografias, foi montado um registro da vida pública, da copresença e das comunidades virtuais recorrentes nos espaços analisados, sob a influência direta da morfologia urbana local (o percurso realizado em cada cidade pode ser visto nas figuras 04,05 e 06 ).

\section{ESTUDO DE CASO}

Este estudo comporta uma análise comparativa, tratando como recorte a área central de três cidades catarinenses (figura 03) Abaixo, são listados os motivos que condicionaram a escolha das cidades como objeto deste estudo.

Inicialmente, por se tratar de assentamentos litorâneos, a situação geográfica das cidades é relevante no que tange sua relação/proximidade com a água. Não obstante, a forma de ocupação desses sítios, de origem luso-brasileira, garante um padrão de ocupação do espaço no que tange à formação das ruas e locação das principais edificações e a relação entre espaço natural e edificado, conforme apresentado anteriormente.

Embora essa aproximação física não seja uma propriedade que define a análise comparativa per se, nesse caso, ela se torna relevante para os termos levantados neste estudo, principalmente ao considerar o

9 "La redución secuencial, cortada de la forma urbana, es un mecanismo de descripción y una estratégia de proyecto." (SOLÀMORALES, 2008, p. 179 texto original) 
potencial de espacialidades e urbanidades para definir padrões de comportamento, uso e apropriação do espaço.

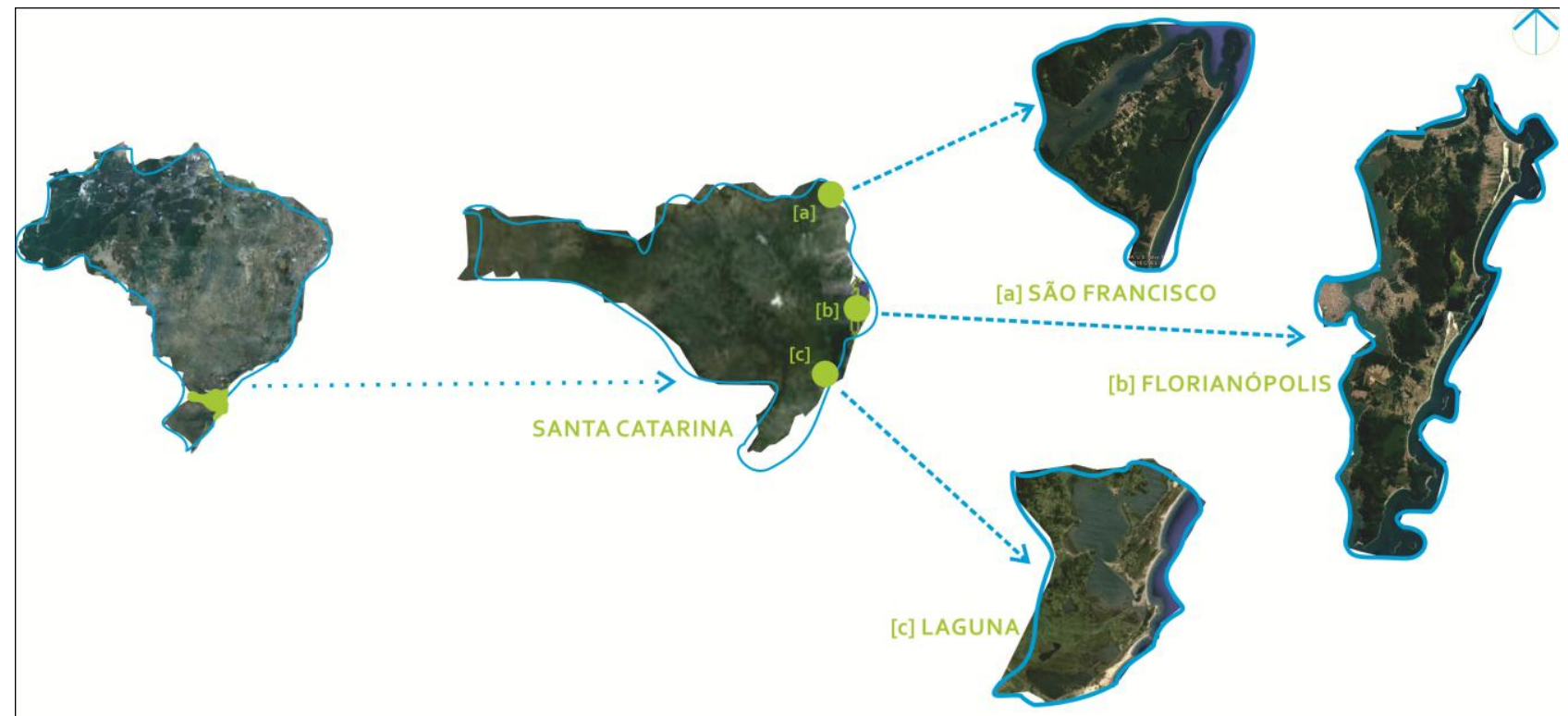

Figura 3 Mapa com a localização do Estado de Santa Catarina e as cidades de São Francisco do Sul, Florianópolis e Laguna Fonte: adaptado de maps.google.com

São Francisco do Sul, Florianópolis e Laguna, respectivamente, conformam os primeiros povoados que consolidaram a ocupação inicial do território de Santa Catarina. Os vilarejos de colonização açoriana surgiram perante a necessidade de guarnecer o território português, na época bastante vulnerável. Para garantir a soberania portuguesa sobre essa porção do território, tornou-se essencial a exploração da região em termos econômicos, assim como a fixação de residência. (Maar et al, 2011).

As áreas selecionadas como enfoque deste trabalho compreendem os espaços centrais dos municípios de Laguna, Florianópolis e São Francisco do Sul, abrangendo os mercados públicos e a orla urbana circundante. O recorte é delimitado com um raio de $350 \mathrm{~m}$ a partir do mercado público (figuras 04,05 e 06 ) compreendendo um trecho importante da orla marítima e outros elementos que são relevantes para essa pesquisa, como a praça e a Igreja.

Dessa forma, o percurso do diário de campo e os cortes urbanos foram elaborados dentro do perímetro determinado, permeando estes equipamentos e tendo como objetivo apresentar elementos da fachada marítima, das relações entre urbano e edificado e das formas de utilização e apropriação do espaço pelas pessoas. 


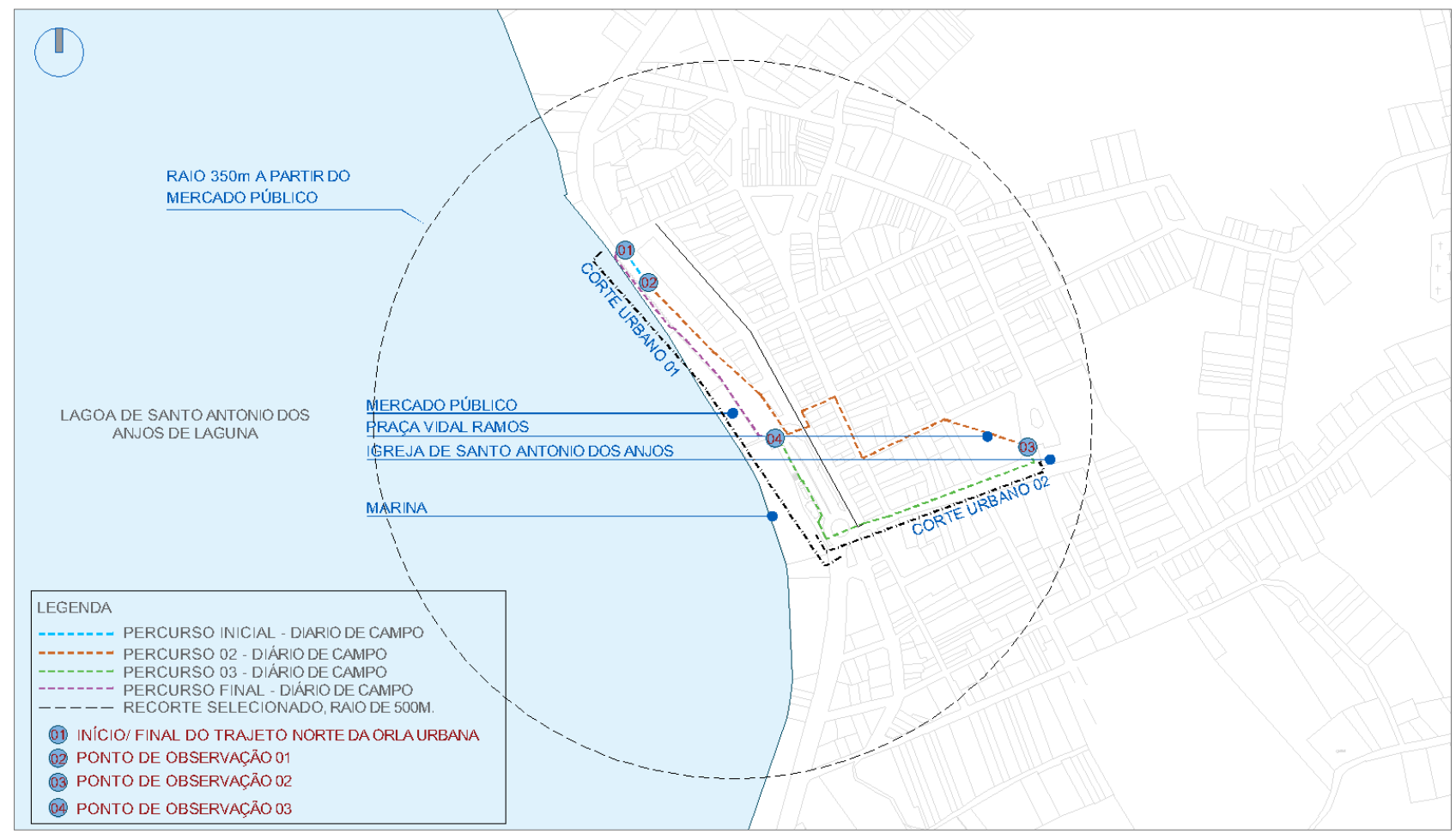

Figura 40 recorte analisado na cidade de Laguna

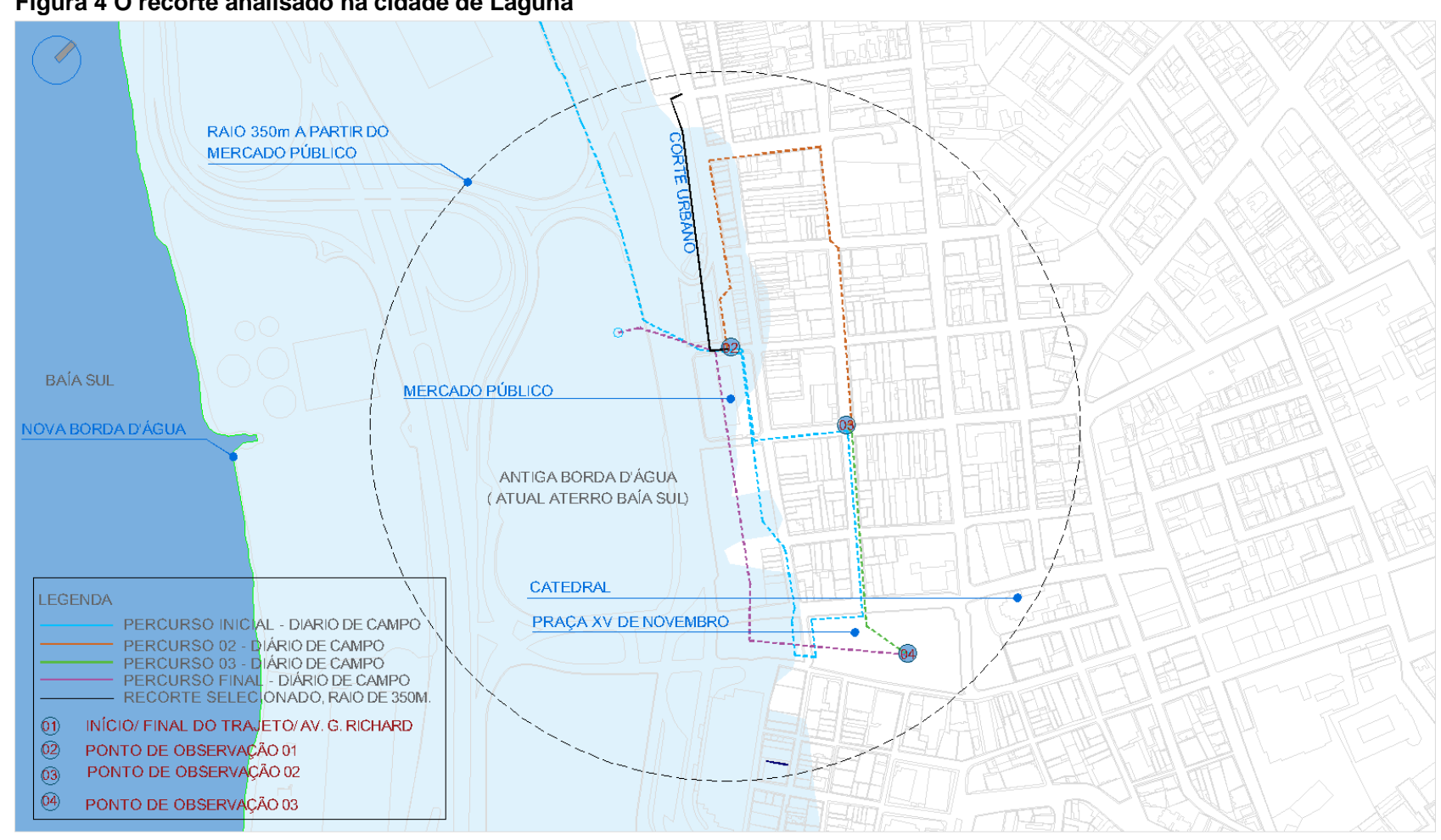

Figura 50 recorte analisado na cidade de Florianópolis 


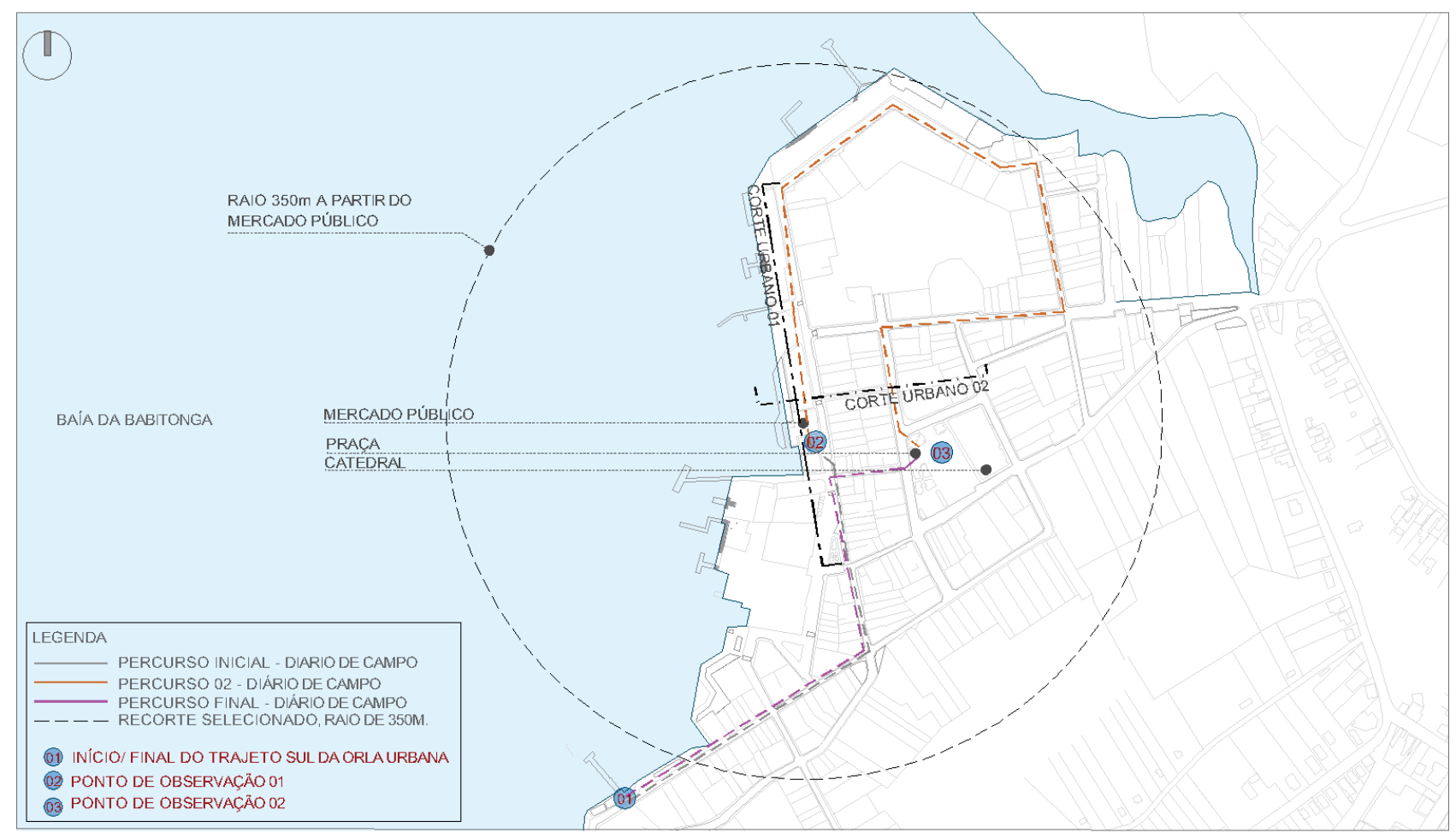

Figura 6 O recorte analisado na cidade de São Francisco do Sul

\subsection{Corte Urbano de Laguna}

O Corte 01 (figura 07), representa a seção longitudinal da Av. Eng. Colombo Salles, e apresenta as edificações voltadas para a orla como limite claro da relação entre público e privado, espaço e edificação. Dentre as propriedades morfológicas analisadas no Corte 01, estão: contiguidade; estilo arquitetônico; uso do solo, temporalidade; diversidade; constitutividade ${ }^{10}$;

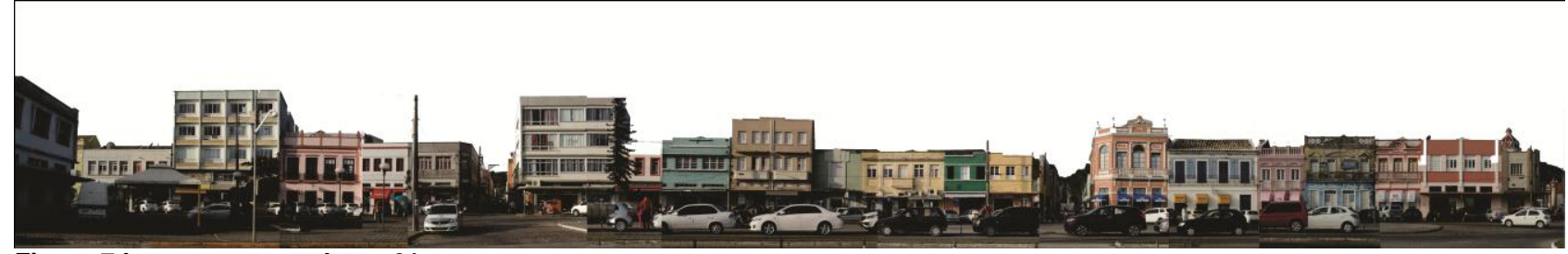

Figura 7 Laguna, corte urbano 01

Podemos observar que as fachadas variam do Ecletismo ao Art-Decô (mesmo estilo do atual mercado público), este que é um estilo mais recente e cuja presença se torna mais frequente à medida que se afasta do núcleo inicial de Laguna, próximo à rua Conselheiro Jerônimo Coelho. As edificações mantém características originais da ocupação ${ }^{11}$, mas o conjunto é violado pela grande quantidade de veículos nas ruas - em movimento tanto quanto estacionados. Predomina a relação entre de intersticialidade do conjunto, resultante da predominância de gabarito de dois pavimentos. Não obstante, em alguns locais, com edificações de até 4 pavimentos que ocupam toda a projeção do lote, estabelecem uma relação de contiguidade, com a presença de empenas cegas nas laterais do lote.

Quanto ao uso do solo, predominam as edificações com uso misto e comercial. Esse conjunto edificado compreende um importante centro de comércio para a cidade de Laguna, e especialmente para o bairro centro. $\mathrm{O}$ uso residencial também se faz presente, porem em menor intensidade.

\footnotetext{
${ }^{10}$ Relações entre espaço interno e externo, através das aberturas das edificações.

${ }^{11} \mathrm{Em}$ 2015, o tombamento do centro histórico de Laguna completou 30 anos. Instituído em 1985, o decreto protege 600 edificações construídas em estilo luso-brasileiro, eclético e art-deco.
} 
Como pode ser observado no diário de campo, essas propriedades do uso do solo fazem com que o movimento de pessoas nas ruas seja intenso durante dias úteis, porém, nos finais de semana e horários hão comerciais, o movimento cai drasticamente, mantido apenas pelas atividades que funcionam nestes horários, como a igreja (figura 8) e o supermercado Angeloni.

Relacionado à constitutividade, outra característica da cidade luso-brasileira, as edificações possuem grande quantidade de aberturas, voltadas para a rua, que garantem vitalidade urbana e permitem estabelecer contato visual entre o interior e o exterior da edificação. Esse elemento é responsável por garantir segurança ao espaço urbano e estimular a vitalidade urbana. (JACOBS, 1961; GEHL, 2013)

O Corte 02, (figura 08) apresenta as relações estabelecidas entre a orla, o mercado, as primeiras edificações da cidade, caracterizadas pela utilização de usos comerciais e de serviços, e por fim a Igreja Matriz.

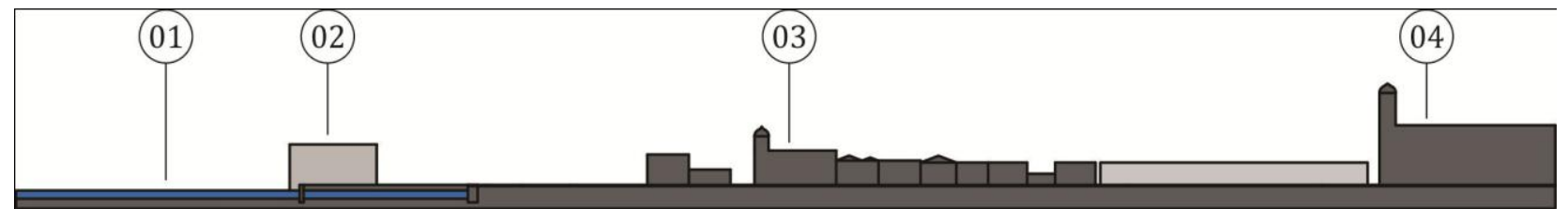

Figura 8 Laguna, corte urbano 02 (1) Lagoa de Santo Antônio dos Anjos (2) Mercado Público (3) Edificações de uso misto, pertencentes ao centro histórico (4) Igreja Matriz.

\subsection{Notas sobre a aplicação do Diário de Campo em Laguna}

Em Laguna, foi possível observar, em um primeiro momento, a predominância e intensidade da circulação de pedestres e de veículos nas ruas, decorrentes das atividades comerciais. Nas calçadas de frente para às edificações, grande parte das pessoas estão em movimento. O fluxo de veículos (principalmente na Av. Engenheiro Colombo Salles) se mostra intenso à ponto de dificultar a passagem de pedestres (à isso somase a ausência de sinalização adequada e faixa de pedestres). Ainda assim, faz-se necessário mencionar algumas pessoas que ficam paradas à sombra das marquises, conversando, e também fazendo uso dos espaços intersticiais (portas e vitrines das lojas) para observar o movimento de pessoas e veículos nas ruas. O passeio à margem da lagoa apresenta a situação inversa: alguns indivíduos circulam - a pé ou de bicicleta - enquanto a grande maioria das pessoas está parada; sentadas nos bancos, em pé observando a lagoa, algumas em grupos conversando, outras sentadas nas mesas próximo à orla. Nota-se também a presença de pescadores que ficam na orla por algumas horas - alguns ficam à manhã toda.

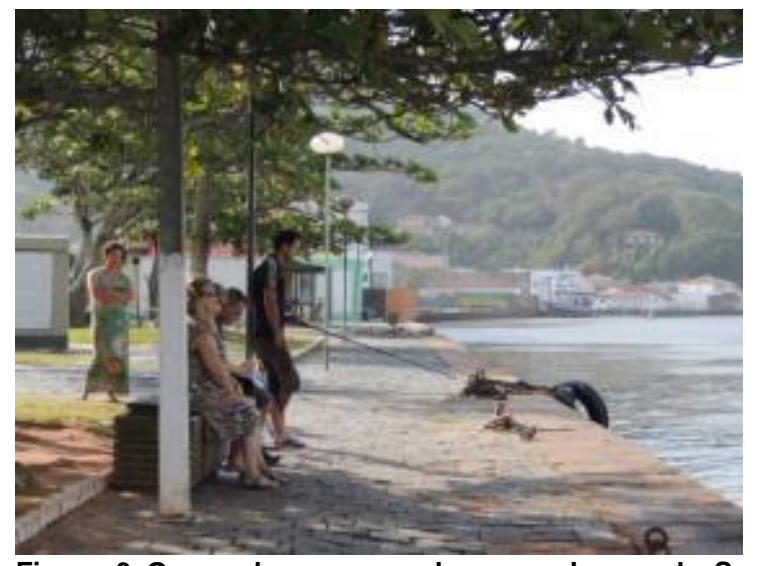

Figura 9 Grupo de pessoas observa a Lagoa de Santo Antônio dos Anjos de Laguna. Em pé, ao fundo, um homem pescando.

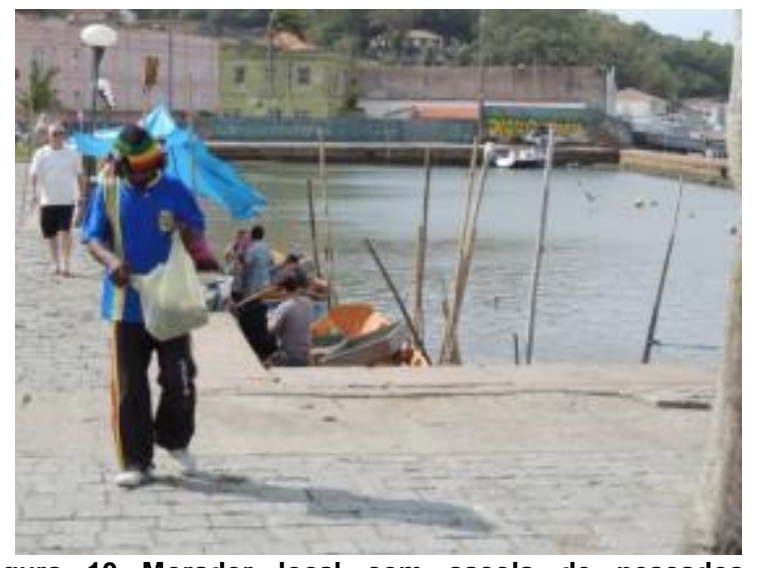

Figura 10 Morador local com sacola de pescados, adquiridos dos vendedores nos barcos (ao fundo)

Nos finais de semana, a situação é bastante diferente. Não há muito movimento de pedestres nas ruas e também há poucos veículos estacionados e em movimento. Esse esgotamento da vitalidade urbana tem aparente relação com os horários em que são desenvolvidas as atividades comerciais. Não obstante, o supermercado Angeloni, situado na porção norte da orla, que permanece aberto aos sábados e domingos, induz à movimentação de pessoas, ciclistas veículos na área do seu entorno. 
Nos finais de semana, a orla também aparenta sem um atrativo à vida pública e, além disso, de permanência. De modo semelhante ao que acontece em dias úteis, há um número considerável de pessoas paradas, sentadas nos bancos, pescando, conversando ou apenas contemplando a visão da lagoa. Ao lado do mercado público, alguns pescadores oferecem virote, anchova, camarão (da lagoa) e siri. A maioria dos peixes são pescados pelos próprios pescadores que estão comercializando o produto, porém, alguns pescados são adquiridos de outros grupos, para serem então revendidos. As vendas ocorrem na marina todas as manhãs, durante os dias úteis da semana, assim como nos domingos (nem todos) e ficam no local até que os pescados se esgotem.

Um pouco afastado da orla, a Igreja também funciona como atrativo à vitalidade urbana. Nos horários que antecedem às celebrações, podemos observar o constante movimento de pessoas, algumas que se aproximam da igreja, e outras que aproveitam alguns minutos na praça.

\subsection{Florianópolis e os aterros}

O recorte urbano selecionado para estudo em Florianópolis compreende a área onde foi iniciada a ocupação urbana do município, caracterizada pela existência de construções de grande relevância histórica e arquitetônica e morfologia urbana característicos, seguindo padrões de ocupação luso-brasileira. Em paralelo a este cenário, o desenvolvimento da capital como polo político e urbano gerou uma série de conflitos de ocupação, que ocorreram principalmente devido ao forte condicionamento da morfologia urbana da cidade pelas condições topográficas do sítio, a saber, os limites territoriais da orla marítima e do Morro da Cruz. Essa característica geofísica alinhada à necessidade de ampliação da infraestrutura urbana convergiu na criação de uma série de aterros nas décadas de 1960 e 1970, sendo o maior deles o Aterro da Baía Sul (figura 11), que alterou consideravelmente uma série de aspectos da área em análise, principalmente com a implantação do sistema de rodovias que acabou por segmentar os espaços públicos afastando-os da orla marítima e diminuindo a proximidade entre cidade e mar.
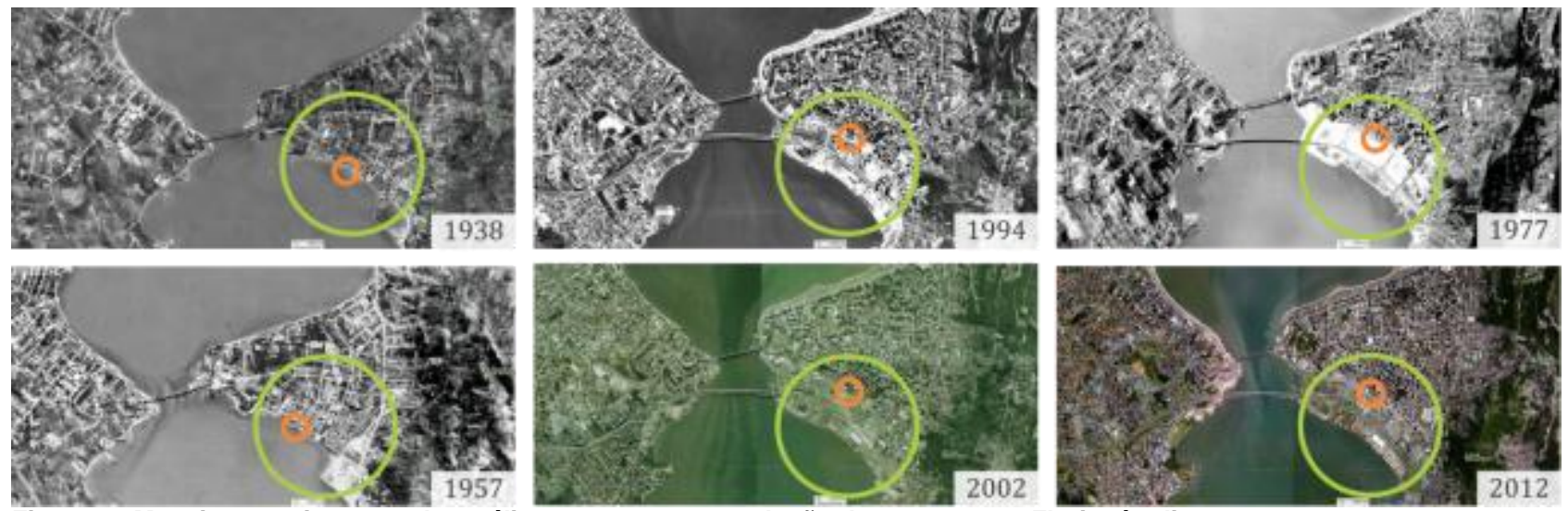

Figura 11 Mosaico com imagens de satélite apresentam a evolução dos aterros em Florianópolis

O espaço criado com o aterro, apesar de ser objeto de uma série de projetos e concursos visando a requalificação da área, ainda possui grande parte de sua extensão ocupada por áreas para estacionamento de veículos, avenidas e vias expressas, permeadas com alguns espaços públicos, e algumas "praças" que não se relacionam com o tecido urbano existente e não se conectam com as áreas onde há o maior fluxo de pessoas. Ao criar um paralelo temporal para a análise da área, há apenas setenta anos atrás a região central de Florianópolis podia ser definida pela singularidade da relação entre seus espaços urbanos com o mar. Passado tanto tempo a singularidade da antiga orla marítima de Florianópolis se tornou inexistente, sobreposta por espaços desqualificados, e pela eminente fragmentação do tecido urbano.

\subsection{Corte Urbano de Florianópolis}

A Figura 12, abaixo, apresenta o corte urbano de Florianópolis. O corte foi traçado na seção longitudinal de Av. Gustavo Richard (antiga rua da orla). Podemos observar, em um primeiro momento, as propriedades de ocupação do lote e de tipologia arquitetônica correntes na cidade luso-brasileira. 


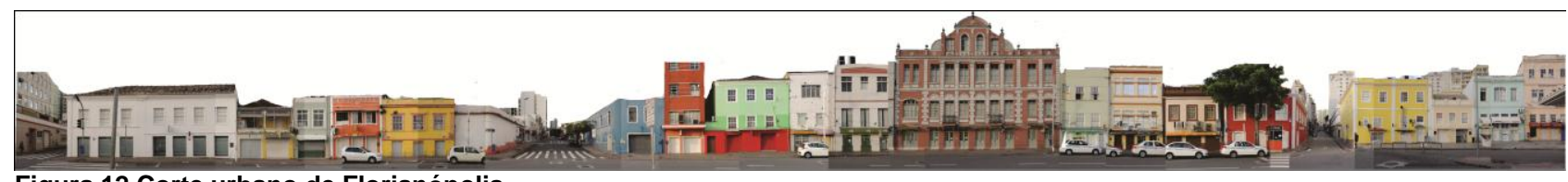

Figura 12 Corte urbano de Florianópolis

O gabarito das edificações varia entre dois e quatro pavimentos, predominando as relações de intersticialidade entre as mesmas, e, em alguns casos, criam-se espaços contíguos, separados pela empena cega na lateral das construções.

De forma semelhante ao que ocorre em Laguna e São Francisco do Sul, o espaço edificado possue uma relação interessante com a rua, com grande numero de portas e janelas que criam uma conexão forte entre interior e exterior; as fachadas das edificações possuem desenhos variados e interessantes, onde predominam o Ecletismo e o Art Decó, mas, nesse caso, completamente desconectadas de sua relação com a orla e com a água. Ainda que é possível notar como esse conjunto remete à primeira linha de edificações da cidade luso-brasileira, o solo criado pelo aterro torna difícil a identificação e relação desses elementos com seu contexto original (figura 13)

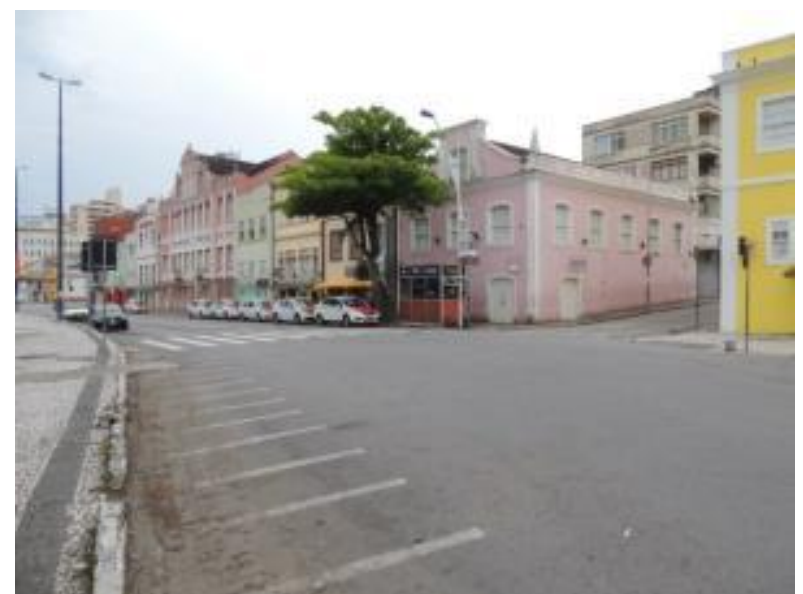

Figura 13 Fachada marítima de Florianópolis. $\mathrm{O}$ asfalto sobrepõe o que antes era a antiga borda d'água

O uso do solo nessa região é predominante comercial, e de serviços, característica do bairro Centro de Florianópolis. Como consequência, esse bairro, que é o "polo comercial" da cidade, é caracterizado pela intensa movimentação de pedestres nos dias úteis, assim como no sábado pela manhã, enquanto à noite e nos demais horários do final de semana, ocorre o processo de "desertificação" do centro. O movimento de pessoas e veículos nas ruas é praticamente nulo, e predomina o sentimento de insegurança.

\subsection{Notas sobre a aplicação do Diário de Campo em Florianópolis}

Em Florianópolis, o que chama a atenção, em um primeiro momento, é a intensidade da vida pública nas ruas do centro - nos dias e horários úteis. São centenas de pessoas em movimento, deslocando-se majoritariamente a pé. A proximidade com o terminal urbano rodoviário (TICEN), e com a Rodoviária Rita Maria, é responsável por grande parte do fluxo de pedestres, paralelamente à centralização de comércio e serviços do bairro Centro e das ruas de uso exclusivamente peatonal. As calçadas do centro também abrigam uma grande quantidade de ambulantes, que comercializam camisetas, frutas, toalhas, óculos de sol, etc. (figura 15) 


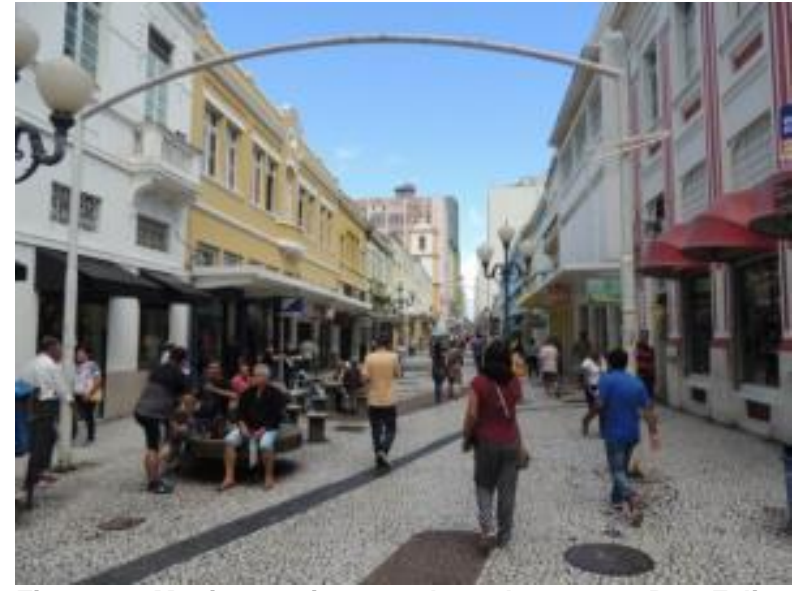

Figura 14 Movimento intenso de pedestres na Rua Felipe Schmitd.

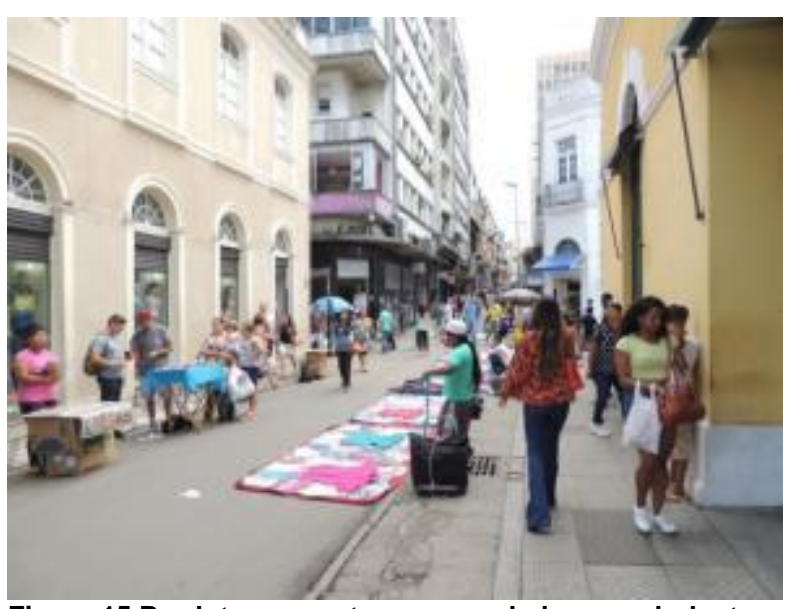

Figura 15 Produtos expostos por vendedores ambulantes ao lado do Mercado Público

Percebe-se que a multidão é composta por pessoas de diferentes classes sociais, renda, e idade. Dentro do mercado público há uma quantidade mensurável de pessoas, a grande maioria em movimento, Os bancos permanecem desocupados, assim como as mesas do vão central do mercado, que só ficam parcialmente ocupadas próximo do horário de almoço.

A Rua Felipe Schmitd (rua peatonal) é onde nota-se o movimento mais intenso de pessoas. Há também artistas de rua, músicos, vendedores ambulantes, pessoas fazendo anúncios e outras jogando cartas e vendendo poemas. Há também algumas pessoas sentadas nos bancos dispostos ao longo da rua.

A praça XV de Novembro também é bastante movimentada durante dias de semana. Os bancos estão praticamente todos ocupados (favorecidos pela sombra das árvores que cria um microclima agradável), e na extremidade norte da praça, próximo à Catedral, são vendidos outros produtos: bolsas, tapetes, caldo de cana, etc.

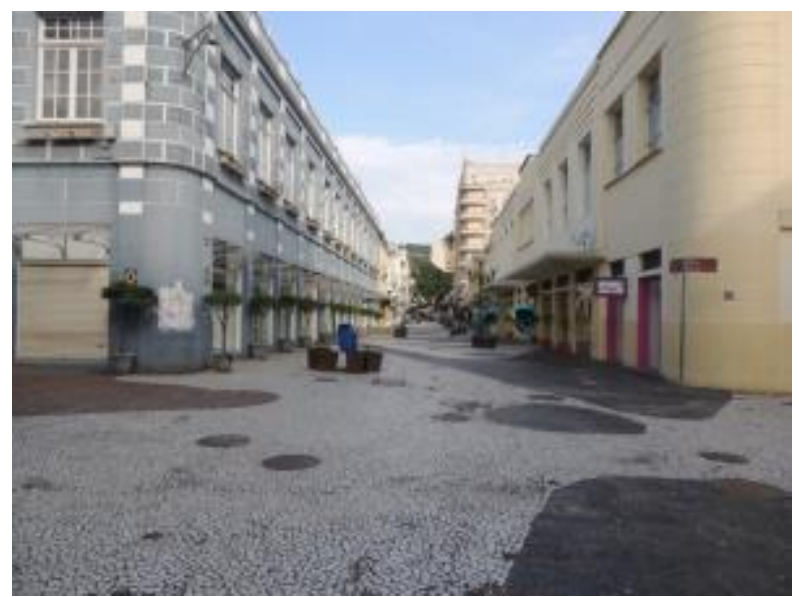

Figura 16 Desertificação da Rua Felipe Schmitd nos finais de semana

O maior problema, não obstante, é que essa vida pública intensa é inexistente nos períodos em que o comércio não opera. A partir das $12 \mathrm{~h}$ de sábado até o início da segunda feira, o centro fica deserto, fenômeno que ocorre também em períodos noturnos (figura 16). Veem-se poucas pessoas nas ruas, apenas alguns mendigos e usuários de drogas, que transmitem o sentimento de medo e insegurança. Nos finais de semana, o único atrativo do centro de Florianópolis são as celebrações realizadas na Igreja. A praça XV de Novembro também fica praticamente desocupada.

\subsection{Corte Urbano de São Francisco do Sul}

O corte urbano de São Francisco do Sul (figura 17) aplicado na seção longitudinal da Rua da Babitonga, apresenta as edificações que compõem a fachada marítima da cidade. Inicialmente, podemos notar que a 
estrutura geral do conjunto é similar às apresentadas anteriormente, de Florianópolis e Laguna. Estas similaridades são decorrentes da tipologia arquitetônica, do estilo das edificações e seu posicionamento no lote, decorrente da ocupação luso-brasileira.

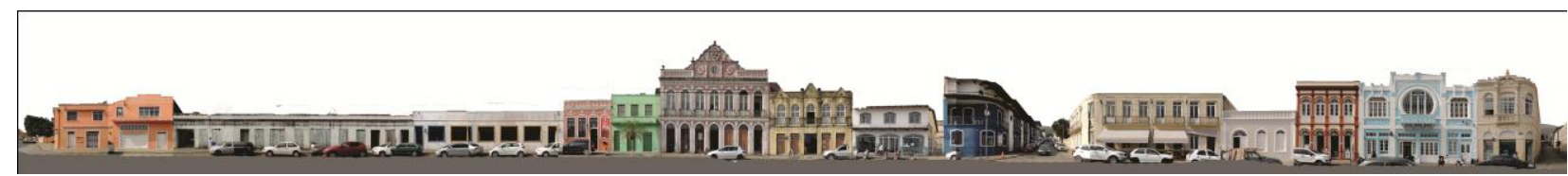

Figura 17 São Francisco do Sul, corte urbano 01

O estilo arquitetônico predominante é o Art-Decó, e o Eclético, o gabarito das edificações mantém-se entre um e dois pavimentos, mantendo relação de intersticialidade, e a ausência das empenas cegas.

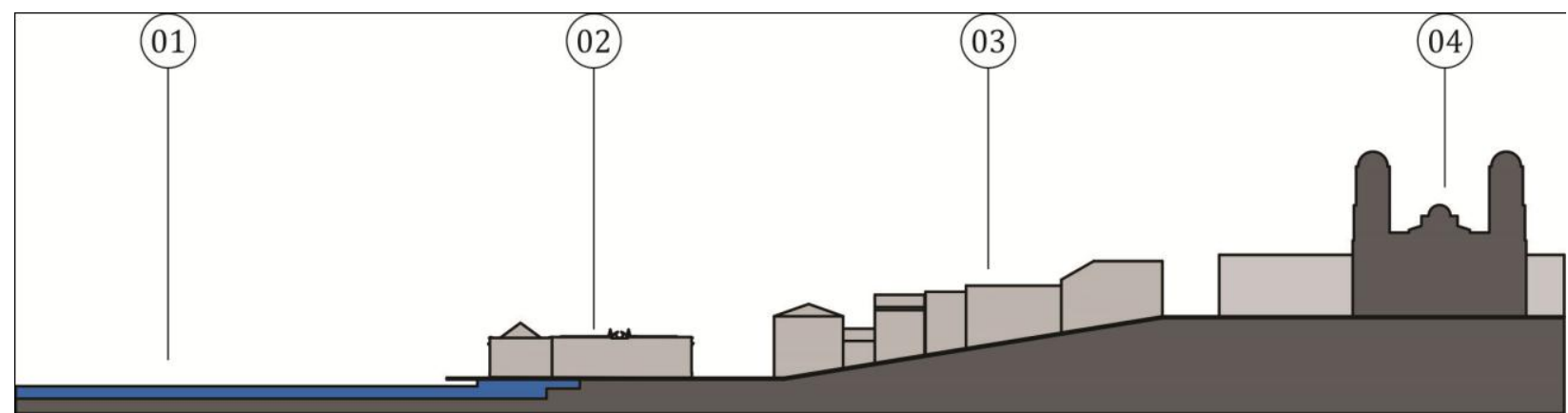

Figura 18 São Francisco do Sul., Corte 02 (1) Lagoa da Babitonga (2) Mercado Público (3) Edificações de uso misto, pertencentes ao centro histórico (4) Igreja Matriz.

Quanto ao uso do solo, predominam as edificações de uso misto e comercial, com algumas residenciais. As edificações possuem grande quantidade de portas e janelas para as ruas, corroborando com a vitalidade do espaço urbano.

\subsection{Notas sobre a aplicação do Diário de Campo em São Francisco do Sul}

Existem feiras de artesanato que ocorrem no trapiche da Baía da Babitonga todos os dias da semana, inclusos os sábados. Os feirantes são da própria cidade e fazem rodízios semanais utilizando as estruturas (de madeira) que foram instaladas no local. (figura 19)

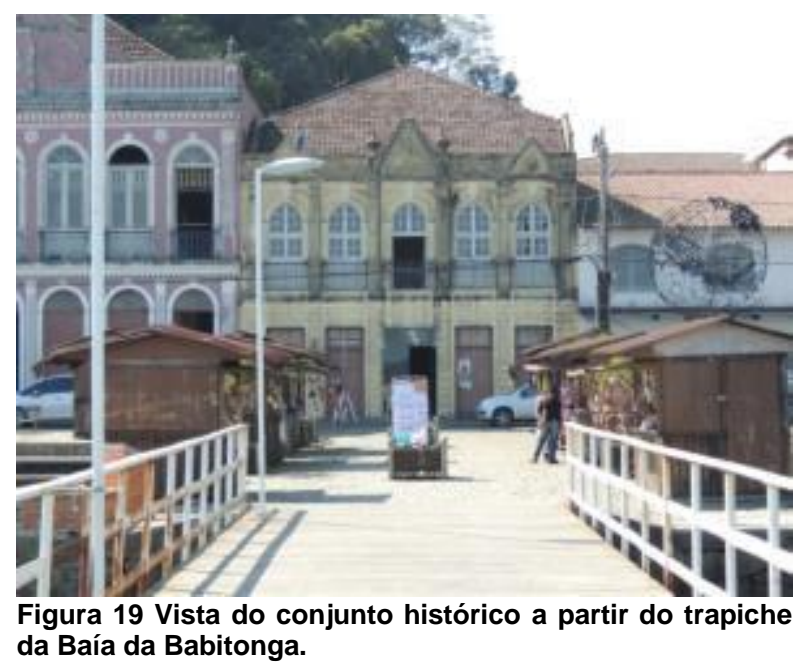

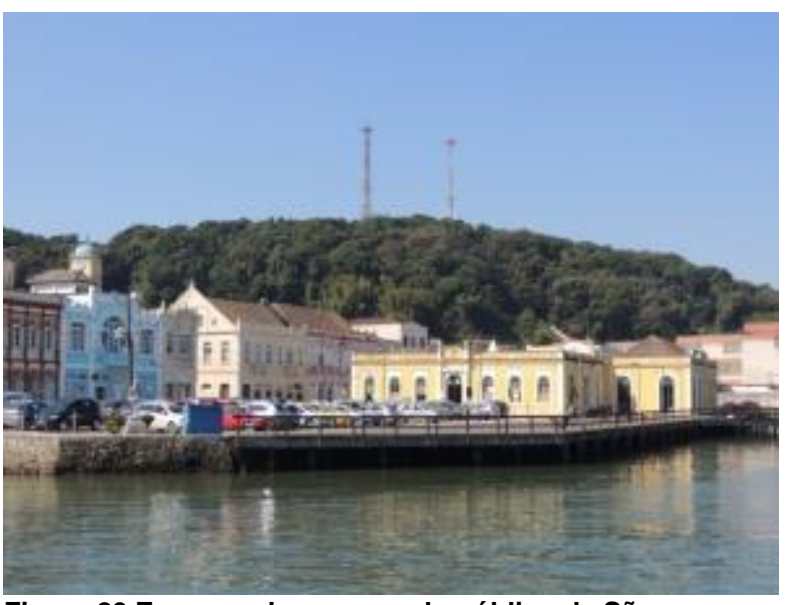

Figura 20 Em amarelo, o mercado público de São Francisco do Sul.

A relação entre edifício e cidade encontrada nos espaços intersticiais da fachada marítima criam uma dinâmica interessante: ao longo do dia pode-se notar várias pessoas que ficavam nas portas e entrada das edificações observando o movimento da rua. Existe um movimento constante de embarcações chegando e saindo da Baía, descarregando os pescados do dia e alguns restaurantes na beira da baía atraem bastante fluxo de pessoas durante o horário de almoço durante os dias úteis e nos sábados. 
Várias pessoas utilizam os bancos dispostos ao longo do deck atrás do mercado público. Sem nenhum motivo aparente, as pessoas aparentam estar passando o tempo, conversando e aproveitando a vista para a água.

Não somente no mercado público, mas em outros locais do centro histórico possuem bancos voltados para a orla, e ao longo do dia pode-se perceber que, em maior ou menor quantidade, sempre havia pessoas sentadas nos bancos.

Em dias úteis, o movimento de pedestres nas ruas é contínuo. Há um número considerável de veículos transitando, além dos automóveis estacionados ao longo do meio fio. Esses automóveis com certeza causam certa confusão visual formando uma barreira que impede a visão entre os lados da rua. Nos finais de semana, em horários em que o comércio não está em funcionamento, nota-se uma redução considerável do movimento de pessoas (e automóveis). Ainda assim, a orla funciona como atrativo, de forma similar ao que foi documentado na cidade de Laguna. Nota-se uma boa relação das pessoas com a água, que perdura ao longo dos finais de semana.

\section{RESULTADOS}

Com a análise realizada sobre as cidades de Laguna, Florianópolis e São Francisco do Sul foi possível identificar as similaridades e disparidades em aspectos relacionados à urbanidade, apropriação dos espaços e sua relação com as respectivas orlas. Um amálgama dos resultados apresenta (i) 0 aterro, no caso de Florianópolis como uma barreira à acessibilidade das pessoas à borda d'água, (ii) a água como elemento fundamental para a manutenção de dinâmicas e rituais próprios de cidades marítimas e para a caracterização da orla; (iii) o mercado público como elemento-chave para a atração de pessoas e manutenção da vitalidade urbana; (iv) os padrões de ocupação (relação lote-edificação) e tipologias de fachada luso-brasileira responsáveis pela manutenção da segurança e vitalidade urbana; (v) a orla dotada de espacialidade e materialidade característicos, geradora de identidade local.

O recorte urbano de Florianópolis foi o que apresentou características mais distintas dentre as áreas analisadas, tendo como maior problemática a remoção da orla do cotidiano das pessoas; consequência direta da criação dos aterros. Com fator positivo no recorte de Florianópolis, foram notados alguns elementos que garantem vitalidade e movimento intenso de pessoas nas ruas, porém, esse fato ocorre somente durante dias de semana, em decorrência do uso terminal urbano e da predominância de comércio e serviços na região do bairro Centro.

Claramente a região carece de atrativos que não funcionem estritamente em horário comercial, em contraste com a realidade atual. A dicotomia existente entre o movimento intenso de pessoas e veículos durante os dias de semana e o isolamento total e desertificação da área nos sábados e domingos é gritante e, por fim, uma característica de desurbanidade.

A desurbanidade encontra-se também no movimento intenso da veículos da Av. Gov. Gustavo Richard, que cria outra barreira que impede o contato (visual, olfativo, auditivo) e aumenta a distâncias entre as pessoas e o mar.

\section{Sobre a água e a importância da orla urbana}

Conforme Jacobs (2009, p. 174) "A própria orla marítima é o primeiro patrimônio desperdiçado capaz de atrair pessoas nas horas vagas", afirmação que mostra-se verdadeira nos casos analisados neste estudo. $O$ diário de campo aplicado em Laguna e São Francisco mostrou que a lagoa de Santo Antônio dos Anjos, e a Baía da Babitonga são elementos usados pelas pessoas para o lazer, pesca, contemplação e navegação. Em São Francisco do Sul a utilização do transporte marítimo pelos pescadores - assim como pelos turistas pode ser verificado com maior intensidade em relação às outras cidades, sendo esse um fator que contribui para a vitalidade local e a manutenção das propriedades originais da baía para a cidade. Em Florianópolis, por outro lado, fora do horário de funcionamento do comércio, a região analisada passa por um processo de desertificação, que poderia ser revertido ou minimizado com a utilização da orla para o lazer das pessoas.

\section{O lugar do mercado público}


O mercado público, estrategicamente posicionado no limite entre a cidade e a borda d'água, outrora caracterizando o papel de porta de entrada de pessoas e mercadorias para a cidade, hoje funciona como fator chave para a atração de pessoas para a região da orla. $O$ mercado estabelece uma conexão entre a força comercial mais influente da urbe, localizada nos conjuntos edificados que compõem a fachada marítima, direcionando as pessoas atraídas pelo comércio também ao longo da orla.

Nota-se em São Francisco do Sul um elo de ligação entre o comércio realizado no conjunto edificado com o mercado público e as tendas de artesanato implantada às margens da Baía. Florianópolis, de forma semelhante, apresenta um elo de integração forte entre mercado público e o comércio formal e informal que ocorre em suas áreas propínquas.

\section{A influência da morfologia urbana luso-brasileira}

O padrão morfológico luso-brasileiro caracterizado pela malha irregular, moldada à condição topográfica e aos limites territoriais impostos pela água e pelos morros também contribuem para alguns aspectos de urbanidade e espacialidade das áreas analisadas. A estrutura viária cria percursos visualmente interessantes, com possibilidades de escolha devido ao tamanho pouco extenso das quadras e por seu formato irregular. $\mathrm{O}$ grande número de aberturas nas fachadas voltadas para a rua em paralelo com a edificação localizada no limite frontal do lote cria uma delimitação clara entre espaço público e privado, permitindo também uma aproximação intensa entre o movimento de pessoas nas ruas e o que ocorre no interior das edificações. Esse fator é reforçado pelo gabarito das edificações, que não ultrapassa os quatro pavimentos.

\section{Apropriação do espaço e vivências urbanas}

O espaço da orla, a rua que precede a primeira linha de edificações possui um atrativo muito forte para as pessoas: a água. E não somente os visuais da lagoa, mas, conforme foi verificado com a aplicação do diário de campo, o cheiro característico da cidade litorânea, o som da água, dos pássaros, o toque da brisa na pele de quem contempla esse encontro entre espaço urbano e espaço natural conformam os elementos enriquecedores da experiência multissensorial e, logo, geradora da identidade local. O que cria uma ambiência tão descaracterizada em Florianópolis é justamente o oposto à esse cenário: a ausência de todos os sinais (visuais, sonoros, olfativos e táteis) que indicam a proximidade da água.

Mesmo que ainda existam fortes indícios da presença anterior da água na região analisada em Florianópolis, estes são principalmente encontrados na tipologia das edificações e no padrão das ruas, o que não é suficiente para criar uma identificação para as pessoas.

\section{CONSIDERAÇÕES FINAIS}

Este estudo foi realizado com o intuito de compreender melhor características de urbanidade, espacialidade e apropriação dos espaços em cidades litorâneas, tendo como objeto de estudo três cidades de origem luso-brasileira, localizadas no estado de Santa Catarina, sul do Brasil. Os resultados encontrados até o atual desenvolvimento da pesquisa mostraram a eficácia do método qualitativo com base na pesquisa etnográfica e na criação e estudo dos cortes urbanos. O trabalho permitiu compreender a importância do mercado público para o contexto municipal e local, e também, o papel que a água teve - e ainda pode ter em cidades litorâneas. Espera-se que este estudo seja parte integrante de um conjunto de pesquisa ainda maior, na busca por entender e mapear as características de urbanidade presente nas cidades litorâneas, e também uma busca por cidades que apresentem uma relação interessante com seus cursos d'água, em muitos casos, abandonados e marginalizados. 


\section{REFERÊNCIAS}

\section{Livros}

AGUIAR, Douglas. Alma Espacial: O corpo e o movimento na arquitetura. Porto Alegre: Ufrgs Editora, 2010. $201 \mathrm{p}$.

CORBIN, Alain. O Território do Vazio: A praia e o imaginário ocidental. São Paulo: Schwarcz, 1989.385 p.

GEHL, Jan; SVARRE, Birgitte. How to Study Public Life. Washington, Dc: Island Press, 2013.

GORSKI, Maria Cecília Barbieri. Rios e Cidades: Ruptura e reconciliação. São Paulo: Senac, 2010.300 p.

JACOBS, Jane. The Death and Life of Great American Cities. New York: Random House, 1961.

MAAR, Alexander; PERON, André; NETTO, Fernando del Prá. Santa Catarina: História, Espaço Geográfico e Meio Ambiente. 2. ed. Florianópolis: Insular, 2011. 283 p.

MARX, Murillo. A cidade brasileira. São Paulo. Melhoramentos. Ed. USP, 1980.

NETTO, Vinicius M. Cidade e Sociedade: as tramas da prática e seus aspectos. Porto Alegre: Sulina, 2014. $431 \mathrm{p}$.

PALLASMAA, Juhani. A Imagem Corporificada: Imaginação e imaginário na arquitetura. Porto Alegre: Bookman, 2013. 152 p.

PALLASMAA, Juhani. Os Olhos da Pele: A arquitetura e os sentidos. Editora Bookman, 2011. 76p.

ROSSI, Aldo. A Arquitetura da Cidade. São Paulo: Martins Fontes, 1995. 309 p.

SOLÀ-MORALES, M. De cosas urbanas. Barcelona: Gustavo Gili, 2008.

TUAN, Yi-fu. Espaço e Lugar: A perspectiva da experiência. São Paulo: Difel, 1983. 250 p.

ULUSSÉIA, Rubens. Laguna, Memória histórica. Editora Letrativa. 409p. 2004.

\section{Capítulos de Livros}

AGUIAR, Douglas. Urbanidade e a qualidade da cidade. In: AGUIAR, Douglas; NETTO, Vinícius M.Urbanidades. Rio de Janeiro: Faperj, 2012. Cap. 2. p. 61-80.

FIGUEIREDO, Lucas. Desurbanismo:: um manual rápido de destruição das cidades. In: AGUIAR, Douglas; NETTO, Vinícius M.. Urbanidades. Rio de Janeiro: Faperj, 2012. Cap. 8. p. 209-234.

KRAFTA, Romulo. Impressões digitais de urbanidade. In: AGUIAR, Douglas; NETTO, Vinícius M..Urbanidades. Rio de Janeiro: Faperj, 2012. Cap. 4. p. 115-134.

NETTO, Vinícius M. A urbanidade como devir do urbano. In: AGUIAR, Douglas; NETTO, Vinícius M..Urbanidades. Rio de Janeiro: Faperj, 2012. Cap. 1. p. 33-60.

TEIXEIRA, Manuel C.. Os modelos urbanos das cidades portuguesas. In: PESSOTI, Luciene; RIBEIRO, Nelson Pôrto. A Construção da Cidade Portuguesa na América. Rio de Janeiro: Pod, 2011. Cap. 10. p. 151169.

\section{Dissertações}

ALBERTI, Ricardo. O caráter urbano da arquitetura: Uma análise entre edifício e cidade na região de Curitiba. 2016. 298 f. Dissertação (Mestrado) - Curso de Programa de Pós Graduação em Arquitetura e Urbanismo, Centro Tecnológico, Universidade Federal de Santa Catarina, Florianópolis, 2016

TEIXEIRA, Luiz Eduardo Fontoura. Espaços Públicos da Orla Marítima do Centro Histórico de Florianópolis: O Lugar do Mercado. 2002. 95p. Dissertação. Universidade Federal de Santa Catarina.

\section{Revistas}

PESAVENTO. Sandra Jatahy. História, Memória e Centralidade Urbana. Revista MOSAICO |Mestrado em História | Pontifícia Universidade Católica de Goiás ,1983.

MAGNANI, José Guilherme Cantor. De perto e de dentro: notas para uma etnografia urbana. Revista Brasileira de Ciências Sociais, São Paulo, v. 17, n. 49, p.11-29, jun. 2002. Mensal.

YAMAMOTO, André R. P. I. Reconstruindo o Mercado Público de Florianópolis. Revista Santa Catarina em História. Florianópolis, v.1, nํ.1. 7p. 2008.

Teses

MELLO, Sandra Soares de. Na beira do rio tem uma cidade: Urbanidade e valorização dos corpos d'água. 2008. 348 f. Tese (Doutorado) - Curso de Arquitetura e Urbanismo, Unb, Brasília, 2008. Disponível em: $<$ http://repositorio.unb.br/handle/10482/1608>. Acesso em: 29 maio 2016.

DEL RIO, Vicente. Desenho Urbano e Revitalização na Área Portuária do Rio de Janeiro. Tese (Doutorado) Faculdade de Arquitetura e Urbanismo da Universidade de São Paulo. São Paulo. 1991. 548p. 